\title{
References
}

1. Ginzburg MR Personal self-determination as a psychological problem. Questions of psychology. M .: Akademiya, 1998. №2. Pp. 18-26.

2. Golovakha E.I. Life perspectives and professional self-determination of youth. K .: Scientific Opinion, 1988. $342 \mathrm{p}$.

3. Dzhura O.D. Cultural field of professional self-identity of a person. Multiversum. Philosophical almanac. Whip 36. K .: Ukrainian Center for Spiritual Culture. 344 pp.

4. Dzhura O.D. The problem of personal and professional self-determination in the theory of vocational guidance (source study base research). Current philosophical and cultural problems of the present: a collection of scientific works. Almanac. K .: Vispol, 2003. 346 p.

5. Handbook on Pedagogy and Psychology: a tutorial for teachers, post-graduate students and students of pedagogical educational institutions; O. V. Skrypchenko, T. M. Lisianskaya, L.O. Skrypchenko. K .: View of the NPU them. MP Drahomanov, 2002. $216 \mathrm{pp}$.

6. Ivanova T.P. I-concept as a component of the professional consciousness of psychologists. Social Psychology. No. 9. 2007. pp. 36-39.

7. Klimov E.A. Psychology of a professional. M. Voronezh, 1998. $126 \mathrm{p}$.

8. Korobova O. Planning the Future - A Way to Succeed. 2010. №45. Pp. 24-28.

9. Brief psychological dictionary; ed. AV Petrovsky Rostov N / A: Phoenix, 1998. 505 p.

10. Pedagogical psychology. Access mode: www. ido success en / psychology / pedagogical_psychology.

11. Proselovna VM Diagnostics of professional self-knowledge of psychologists-practitioners: author's abstract. ... Candidate psychologist Sciences: special 19.00.07. Kazan: [b. and.], 2001. 26 p.

12. Pryazhnikova E. Yu. Factors of professional self-determination of teachers of pedagogical high schools. Questions of psychology. 1994. No. 6. P. 65-73.

13. Stanovsky Z.L. Actual problems of professional development of the personality of future practical psychologists. Collection of materials of the All-Ukrainian scientific and practical conference on May 16-17 "Problems of preparation and improvement of professional skills of practical psychologists in higher educational institutions", ed. S.D. Maximenko K., Ternopil: Nika-center, 2002. 49-52.

14. Terentyeva V.A. Motivation to succeed as a leading factor in the success of a student's academic activity. K .: (University Readings 2006). M., 2006. 260 p.

15. Schneider L. B. Professional Identity: Monograph. M .: MOSU, 2001. 272 p.

Одержано статтю: 03.07.2019

Прийнято до друку: 17.07.2019

УДК 378:373.2011.3-51

DOI: $10.15330 /$ esu. $16.109-116$

\section{Ірина Онищук,}

кандидат педагогічних наук, доцент, Кременецька обласна гуманітарно-педагогічна академія ім. Тараса Шевченка (м. Кременець, Україна).

Iryna Onyschuk, Candidate of pedagogical sciences $(\mathrm{PhD})$, Associate Professor, Kremenets Regional Humanitarian and Pedagogical Academy named after Taras Shevchenko (Kremenets, Ukraine) ionuschyk@gmail.com

\section{АНАЛІЗ ЧИННИКІВ РОЗВИТКУ КУЛЬТУРИ САМОВИРАЖЕННЯ МАЙБУТНІХ ВИХОВАТЕЛІВ ЗДО У ХУДОЖНІЙ ДІЯЛЬНОСТІ}

\section{ANALYSIS OF THE FACTORS OF DEVELOPMENT OF THE SELF-EXPRESSION CULTURE OF FUTURE IPE TEACHERS IN ARTISTIC ACTIVITY}

Стаття присвячена висвітленню однієї із актуальних проблем сучасної вищої педагогічної освіти - підготовиі фахівців дошкільної освіти, оскільки на сьогодні певною мірою саме від них буде залежатиме осучаснення підходів до освітнього прочесу на периій освітній ланці. Увага зосереджуеться на таких ключових питаннях як особистісно- 
професійне становления майбутнього фахівчя, розвиток культури самовираження молодой людини на основі аналізу наукових прачь з філософії, психології та педагогіки. У публікачії окреслені основні аспекти науково-дослідної діяльності у означеному напрямі, а саме: визначено мету та периочергові завдання, передбачено науково-обгрунтовані иляхи виріиення проблеми. Досліджуване явище кваліфікується як особливості (відмінні від іниих людей властивості особистості), способи (систематизовану сукупність дій, використаних для досягнення мети), результати (проміжні та кінцеві продукти) самоорганізованої професійної діяльності.

На основі аналізу психолого-педагогічної літератури розглядаються структурні компоненти (когнітивний, емоційно-иіннісний, поведінковий). Визначаються критеріӥ та показники очінки міри сформованості культури самовираження, роль яких виконують властивості особистості майбутніх фахівиів доикільної освіти, що відповідають основним векторам педагогічної діяльності (діловому, аксіологічному, комунікативному, перетворювальному та на иій основі визначається типологія сформованості досліджуваного явища. Зокрема, значний акиент надасться аналізу важливих чинників розвитку культури самовираження майбутніх фахівців дошкільної освіти; висвітленню організаційно-педагогічних умов, ефективних форм, методів та прийомів; окреслюються перспективи наукової розвідки. Зазначається також, що концепчія дослідження забезпечується єдністю методологічного, теоретичного та методичного аспектів.

Ключові слова: особистісно оріснтована освіта, культура самовираження, майбутні вихователі закладів дочкільной освіти, художня діяльність, організачійнопедагогічні умови, чинники розвитку культури самовиражения.

The article is devoted to the coverage of one of the topical issues of modern higher education - training of preschool education specialists, since today to a certain extent it will depend on them to modernize the approaches to the educational process at the first educational level. Attention is focused on such key issues as the personal and professional formation of a future specialist, the development of the culture of self-expression of a young person on the basis of the analysis of scientific works on philosophy, psychology and pedagogy.

The publication outlines the main aspects of research activities in the specified direction, namely: the purpose, the priority tasks and the scientifically substantiated ways of solving the problem are provided. The investigated phenomena are qualified as peculiarities, ways and results of self-organised professional activity. In particular, the structural components (cognitive, emotional, and behavioral) are specified on the basis of the nail of psychological and pedagogical literature; criteria and indicators of estimation of the formation of the culture of self-expression are singled out; criteria and indicators of estimation of the formation of the culture of selfexpression, which are the characteristics of the personality of future specialists in preschool education, are singled out, corresponding to the main vectors of pedagogical activity (business, asciiological, communicative, transformative) and on this basis the typology of the formed phenomenon is determined.

In particular, special attention particular (special) attention is paid to the analysis of important factors in the development of culture self-expression of future specialists of preschool education; is paid to the clarification of organizational and pedagogical conditions, effective forms, methods and methods; outlines prospects for scientific intelligence.

It is also noted that the concept of research is ensured by the unity of methodological, theoretical and methodological aspects.

Key words: person-oriented education, culture of self-expression, future educators of preschool establishments, artistic activity, organizational and pedagogical conditions; self-expression factors of development in artistic activity.

Постановка проблеми. На часі особистісно орієнтована освіта, оскільки фахівці визначають пріоритет розкриття та розвитку потенціалу особистості, 
ставлення до неї як до суб'єкта життєдіяльності. Особливої значущості зазначене набуває стосовно підготовки майбутнього педагога, зокрема вихователя закладу дошкільної освіти, що дає змогу подолати однозначність і універсальну методичну рецептурність професійної підготовки $[1 ; 2 ; 3 ; 5 ; 8 ; 9]$. Професійна діяльність, за висновками науковців, с один із основних способів здійснення життя та особистісної самореалізації - прагнення людини здійснити себе через свою професійну діяльність визначається як одна 3 основних культурних цінностей $\mathrm{i}$ основне завдання професійної освіти $[1 ; 2 ; 3 ; 4 ; 5 ; 8 ; 9]$.

3-поміж актуальних проблем сучасної вищої освіти $\epsilon$ розвиток культури самовираження майбутніх фахівців дошкільної освіти. На сьогодні накопичився чималий науковий доробок, який висвітлює аспекти означеного феномену, а саме: теоретико-методологічні засади організації освітнього процесу у вищій школі (В. Андрущенко, І. Бех, О. Киричук, В. Кремень, І. Зязюн, В. Луговий, О. Сухомлинська та інші); професійна підготовка майбутніх закладів дошкільної освіти (Л. Артемова, Г. Бєлєнька, О. Богініч, А. Богуш, Н. Гавриш, Н. Гузій, І. Дичківська, Л. Зданевич, О. Кононко, І. Княжева, І. Луценко, Н. Лисенко, О. Лисенко, О. Листопад, О. Олійник, Ю. Косенко, Н. Маковецька, С. Нечай, І. Рогальська-Яблонська, Т. Танько та інші); естетико-педагогічні харакретистики художньої культури (О. Берегова, І. Зязюн, А. Козир, Л. Левчук, О. Комаровська, Г. Локарєва, Л. Масол, Н. Миропольська, Г. Падалка, О. Рудницька, Г. Сотська, О. Отич, Г. Шевченко та інші).

Важливо зазначити, незважаючи на вагомий науковий доробок, проблема розвитку культури самовираження студентської молоді у художній діяльності вивчена в неповні мірі. Отож, виникає потреба в дослідженні механізмів, виявлення чинників розвитку культури самовираження майбутніх вихователів закладів дошкільної освіти у художній діяльності.

Мета статті - проаналізувати чинники (зовнішні та внутрішні) розвитку культури самовираження майбутніх вихователів ЗДО у художній діяльності.

Виклад основного матеріалу. У процесі проведення констатувального експерименту виявлено, що типи культури самовираження студентської молоді у художній діяльності визначаються низкою чинників - внутрішніх і зовнішніх. Обмеженість рамок наукового дослідження обумовило необхідність зосередитися на основних з них з метою використання у процесі розробки моделі оптимізації процесу розвитку у майбутніх вихователів ЗДО культури самовираження у художній діяльності.

Оперуючи поняттям внутрішні чинники, ми мали на увазі індивідуальні особливості майбутніх вихователів ЗДО, які забезпечують зміни та прогресивний характер еволюції їхньої культури самовираження у художній діяльності. До них віднесено:

- особистісну та професійну самооцінки, їх співвідношення;

- потребу у зовнішній підтримці;

- інтерес до художньої діяльності, здібності до неї;

- самоповагу та саморегуляцію поведінки;

- суб'єктну оцінку оптимальної, бажаної та реальної міри розвитку культури самовираження;

- впевненість або невпевненість та незалежність або залежність активності досліджуваних. 
У процесі аналізу проявів майбутніми вихователями культури самовираження у художній діяльності фіксувалися особливості впливу на досліджуване явище таких зовнішніх чинників як:

- відображення проблеми формування у студентської молоді культури самовираження взагалі, у художній діяльності зокрема, у змісті професійної підготовки майбутніх вихователів;

- інтеграція різних видів художньої діяльності та варіювання форм іiї організації;

- атмосфера у професійному оточенні;

- ставлення до успіхів та невдач досліджуваних значущих для них людей (викладачів, одногрупників);

- надання студентам права на вибір.

\section{Аналіз ролі внутрімніх чинників розвитку досліджуваного явища}

Зупинимося на аналізі впливів на культуру самовираження майбутніх вихователів у художній діяльності внутрішніх чинників, пов'язаних з уявленнями досліджуваних про самих себе та майбутню професійну діяльність, умінням виробляти самооцінні судження, цінувати себе та регулювати свою поведінку. Перераховані вище суб' єктивні характеристики особистісного зростання дозволяють говорити про те, що розвиток кожної та усіх разом визначається сформованістю у майбутніх вихователів позитивної й адекватної “Я-концепції”. За висновками І.Кона "Я-концепція" є внутрішнім усвідомленням особистістю самої себе, здатністю себе оцінити, відчувати відповідальність за своє життя (особисте та професійне), умінням контролювати власну поведінку. Зазначені прояви безпосередньо залежать від рівня розвитку самосвідомості студентів. У дослідженні ми базуємося на думці вказаного автора, згідно 3 якою особистість 3 високим рівнем розвитку самосвідомості добре диференціює свої чесноти i вади, орієнтується в основних особливостях, вирізняється здатністю до педагогічної рефлексії.

На думку науковців, чим глибша самосвідомість особистості, тим ефективніше вона діє - адже усвідомлене ставлення до власних потреб, адекватна оцінка своїх можливостей і здібностей дозволяє студентові доцільно коректувати життєві сценарії. Звідси випливає висновок: адекватне уявлення майбутніх вихователів $3 Д О$ про себе $\epsilon$ важливою умовою досягнення успіхів в освітньому процесі взагалі, у самовираженні в художній діяльності зокрема. Слабка "Я-концепція" виступає бар'єром у досягненні успіху внаслідок низької самооцінки та суб'єктивного, здебільшого вельми обмеженого сприйняття майбут6німи вихователями своїх особистісних властивостей, невисоких очікувань щодо себе $[1 ; 4]$. У ході аналізу емпіричних даних увагу акцентовано на виділених провідними фахівцями базових компонентах “Я-концепції досліджуваних", а саме: розумінні себе, впевненості у соб̈і, емоиійній стійкості. Базуючись на них, характеризуватимемо особливості розвитку у майбутніх вихователів “Я-концепції" як важливої передумови розвитку культури самовираження у художній діяльності. Нижче у таблиці 1. наведено узагальнені дані опитування та проективних методик констатувального етапу дослідження. 
Таблиця 1.

Розподіл досліджуваних різних типів культури самовираження за розвитком базових характеристик “Я-концепції” у балах на констатувальному етапі дослідження

\begin{tabular}{|l|c|c|c|}
\hline \multirow{2}{*}{ Типи самовираження } & \multicolumn{3}{|c|}{ складові “Я-концепції" } \\
\cline { 2 - 4 } & Розуміння себе & $\begin{array}{c}\text { Впевненість у } \\
\text { собі }\end{array}$ & Стійкість емоцій \\
\hline ДУХОВНИЙ & 10 & 10 & 10 \\
\hline ОСОБИСТІСНЙ̆ & 10 & 9 & 8 \\
\hline СУБ'СКТНЙ̆ & 8 & 7 & 6 \\
\hline БАЗОВЙ̆ & 5 & 4 & 1 \\
\hline ДЕСТРУКТИВНЙ̆ & 3 & 2 & 4 \\
\hline
\end{tabular}

Наслідком здійсненого якісного аналізу наведених у таблиці 4.8 кількісних даних стосовно розвитку у досліджуваних “Я-концепції" слугують, такі узагальнення:

1. Порівняння оцінок знань досліджуваними себе як особистості та фахівця 3 впевненістю у собі й стійкістю емоцій, можна говорити, що система знань переважної більшості майбутніх вихователів ЗДО сформована краще, ніж довіра власним можливостям та саморегуляція емоцій та дій в освітньому процесі та художній діяльності.

2. Встановлено, що лише представники духовного та особистісного типів розвитку культури самовираження характеризуються високими оцінками саморозуміння, впевненості у собі та емоційної стабільності. Віднесені до суб'єктивного та базового типів культури самовираження студенти характеризувалися проміжними оцінками, які засвідчують їню залежність від ситуації, складності та новизни завдання, необхідності виявити творчу ініціативу. Як і очікувалося, найнижчі оцінки отримали самооцінки, впевненість у собі та стійкість емоцій представників деструктивного типу - невпевнених у собі, імпульсивних досліджуваних, знання яких про себе виявилися клаптевими, схематичними, а самооцінки невпевненими або низькими. Дехто з них взагалі уникав необхідності оцінювати себе або відповідав: "Не знаю", "Мені важко відповісти” та інші.

3. Досліджено, що близько двох третин майбутніх вихователів визнали, що, як правило, невпевнені у собі, бояться помилитися, зробити щось неправильно, бути осудженими авторитетними людьми, у першу чергу, викладачами та референтною групою одногрупників. Вони усвідомлюють негативний вплив непевності у собі на уміння культурно самовиражатися освітньому процесі взагалі, у художній діяльності зокрема. Типовими виявилися такі висловлювання: "Творчому самовираженню заважає моя невпевненість”, “Виражати себе у художній діяльності, думаю про те, як мене оцінять оточуючі", "Я б краще самовиражалася, якщо б постійно не сумнівалася у своїх можливостях", “Працюю і думаю - чи вийде в мене так, як хочу”, “Я невисокої думки про свої здібності”. Отже, розвиток позитивної думки про себе - важливий напрям подальшої роботи 3 даною категорією досліджуваних.

4. Водночас інші 75\% майбутніх вихователів зазначили, що успіх їхньої діяльності значною мірою залежить від зовнішніх впливів: “Знання та думки інших людей відіграють для мене важливу роль”, “Підтримка близьких людей мені вкрай потрібна”, “Допомога інших позитивно позначається на результатах", “Поради, як зробити краше,надихають на подальший пошук”. 
Наведені висловлювання засвідчують особливості оцінок представниками кожного типу розвитку культури самовираження значення реалізації "Я" професійній діяльності. Узагальнюючи їх, можна схарактеризувати типові для кожної категорії досліджуваних установки:

- духовного - масштабність, баланс індивідуального та соціального, прагнення самовдосконалення;

- особистісного - визнання важливості самовизначення, реалізації свого потенціалу, орієнтація на цінності справедливості, щирості, власної гідності;

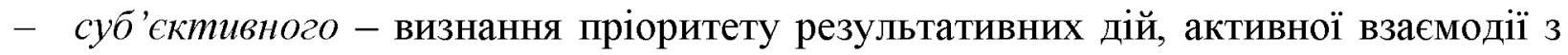
колегами та дошкільниками, професійної етики;

- базового - надання переваги дотриманню вимог і правил, проявам ввічливості й доброзичливості, необхідності бути для дітей зразком для наслідування;

- деструктивного - несформованість адекватної оцінки ролі самосвідомості у майбутній професійній діяльності.

Отже, актуалізується необхідність спеціальної організації освітньої роботи, спрямованої на вправляння майбутніх вихователів в уміннях адекватно себе оцінювати, поводитися впевнено та виявляти оптимізм під час виконання завдань художнього характеру. При цьому важливе застосування диференційованого підходу до розвитку самосвідомості представників принаймні трьох 3 п'яти типів культури самовираження - суб'єктного, базового та деструктивного. Це пояснюється необхідністю брати до уваги специфічні для кожної категорії досліджуваних особливості сформованості у них знань, ставлення та стилю поведінки в ситуаціях, які пред'являють вимоги до їхнього уміння культурно самовиражатися, діяти свідомо, впевнено, творчо.

Нижче зупинимося на аналізі зовнішиіх чинииків, які вплинули на культуру самовираження досліджуваних у художній діяльності.

До основних 3 них віднесено:

- усвідомлення викладачами змісту й функцій художньої діяльності у сучасних реаліях;

- широту представленості та міру збалансованості у навчальних програмах видів художньої діяльності;

- урізноманітнення форм ¥ї організації у процесі підготовки майбутніх вихователів, надання досліджуваним права на творчість.

Аналіз ролі зовнішніх чинників розвитку досліджуваного явища

Упровадження у закладах вищої освіти гуманістичної парадигми обумовило необхідність поглибленого аналізу особливостей організації художньої діяльності 3 метою залучення студентської молоді до духовної культури, діяльності із створення духовних цінностей, реалізації свого творчого потенціалу, освоєння накопиченого соціального та духовного досвіду. Також нас цікавило, наскільки художня діяльність досліджуваних спрямована на розвиток у них позиції суб'єкта, збагачення духовнопрактичного ставлення до світу, окультурення потреб та плекання соціально прийнятних форм самовираження.

Аналізуючи дані констатувального експерименту, ми виходили 3 розуміння, що в процесі професійної підготовки вихователів художній діяльності має приділятися особливе місце. Це, зокрема, пов'язане із специфікою роботи вихователя, 3 необхідністю опори на емоційно-чуттєвий досвід пізнання світу дітьми дошкільного віку. У процесі перетворювальної, духовно-пізнавальної, оціночної та комунікативної діяльностей майбутній вихователь ЗДО має оволодіти комплексом важливих 
художньо-педагогічних умінь: уміннями організовувати та управляти педагогічним процесом в його художньому втіленні, імпровізувати, усвідомлювати власну індивідуальність. У такий спосіб майбутній вихователь вдосконалюється як особистість, оволодіває здатністю ціннісно ставитися до своєї професійної діяльності.

Сучасні реалії актуалізують окрім педагогічної і соціальну функцію мистецтва та художньої діяльності. Твори мистецтва утворюють сферу культури українського суспільства. Важливі самі по собі, вони набувають особливого значення в аспекті їх соцііального функціонування. Врахування у процесі підготовки майбутніх вихователів закладів дошкільної освіти соціальної компоненти художньої діяльності означає націленість викладачів закладів вищої освіти на культурне освоєння студентами соціального простору, виховання у них соціальної компетентності, збалансованість індивідуальних та колективних інтересів, формування умінь працювати у команді (домовлятись, узгоджувати свої дії, брати до уваги потреби інших, поступатися, приймати компромісні рішення, визнавати помилки та досягнення - власні та інших людей, відстоювати істину), цінувати свої досягнення, презентувати їх широкому загалу.

3 огляду на сказане вище, на часі забезпечення єдності педагогічної, соиіальної та психологічної компонент художньої діяльності. Вона сприятиме вихованню гармонійно та різнобічно розвиненої особистості майбутнього вихователя ЗДО, реалізації системного підходу у процесі підготовки майбутніх вихователів освіти до професійної діяльності та організації художньої діяльності (власної та дітей дошкільного віку). Таким чином, вдосконалення змісту програм має базуватися на ідеї, згідно 3 якою художня діяльність розуміється як складний феномен, який має, з одного боку, поєднувати психологічний, педагогічний та соціальний компоненти, з іншого - функціонувати у процесі підготовки майбутніх вихователів на трьох рівнях - методологічному, діяльнісному та особистісному.

Висновки. На констатувальному етапі дослідження розроблено комплексну і варіативну методику, яка забезпечила обгрунтоване діагностування особливостей розвитку культури самовираження майбутніх вихователів закладів дошкільної освіти у художній діяльності та визначення чинників, що детермінують розвиток даного явища.

До внутрішніх віднесено особливості розвитку у досліджуваних самосвідомості: уявлення про себе як особистість та професіонала, характер самооцінки, ціннісне самоставлення. До складу зовнішніх чинників увійшли: зміст та види художньої діяльності, їх інтеграція в освітньому процесі, форми організації самостійної художньої діяльності студентів, надання їм права на прояв творчості. Встановлено, що оптимізація освітнього процесу, спрямованого на розвиток у майбутніх вихователів ЗДО культури самовираження у художній діяльності, передбачає необхідність врахуваннях у процесі підготовки майбутніх вихователів як перших, так і других чинників, оскільки за відсутності їх балансу відбувається трансформація та уповільнення особистісного та професійного зростання студентської молоді.

Література

1. Бех І. Д. Виховання особистості: у 2 кн. Кн.: 2: Особистісно орієнтований підхід: науковопрактичні засади. - К.: Либідь, 2003. - $344 \mathrm{c}$.

2. Васильєва М.П. Культурологічний підхід до процесу професійної підготовки майбутнього педагога. Педагогіка і психологія творчої особистості: проблеми і пошуки: зб. наук. праць. Вип. 47. - Запоріжокя, 2007. - С. 67. 
3. Зязюн I. А. Концептуальні засади теорії освіти в Україні // Педагогіка і психологія професійної освіти . 2000. - № 1. - C. 11-24.

4. Кононко О. Л. Культура самовираження майбутніх педагогів як особистісний феномен // Збірник тез наукових робіт учасників міжнародної науково-практичної конференції "Психологія та педагогіка: необхідність впливу науки на розвиток практики в Україні". Львів : ГО “Львівська педагогічна спільнота", 2017. - С. 13-18.

5. Кремень В.Г. Духовність і культура суспільства визначаються розвитком освіти.Освіта у полікультурних суспільствах за редакцією Василя Кременя, Тадеуша Лановицького, Сжи Нікіторовича, Світлани Сисоєвої. - Вища педагогічна школа СПВ. Університет Бялостоці. Варшава, 2012. - 392 с. - С. 45-55.

6. Кримський С. Б. Культура розкриває внутрішню безмежність людини / Культурологічна думка. - 2009. - № 1. - С. 18-26.

7. Омельченко Е.А. Самовыражение и культура самовыражения педагогов и студентов педагогических ВУЗов / Теория и практика образования в современном мире : материалы II международной научной конференции. - СПб. : Реноме, 2012. - С. 11-14.

8. Підготовка вихователя до розвитку особистості дитини в дошкільному віці : монографія за заг. ред. І. І. Загарницької. - К.: вид-во НПУ ім. М. П. Драгоманова, 2009. - 310 с.

9. Сисоєва С. О. Основи педагогічної творчості : підручник. - К.: Міленіум, 2006. -344 с.

\section{References}

1. Bekh I. D. Vykhovannia osobystosti: u 2 kn. - Kn. 2: Osobystisno oriientovanyi pidkhid: naukovopraktychni zasady. - K. : Lybid, 2003. - $344 \mathrm{~s}$.

2. Vasylieva M.P. Kulturolohichnyi pidkhid do protsesu profesiinoi pidhotovky maibutnoho pedahoha // Pedahohika i psykholohiia tvorchoi osobystosti: problemy i poshuky: zb. nauk. prats. Vyp. 47. Zaporizhia, 2007. - S. 67.

3. Ziaziun I. A. Kontseptualni zasady teorii osvity v Ukraini / Pedahohika i psykholohiia profesiinoi osvity. - 2000. - \# 1. - S. 11-24.

4. Kononko O. L. Kultura samovyrazhennia maibutnikh pedahohiv yak osobystisnyi fenomen // Zbirnyk tez naukovykh robit uchasnykiv mizhnarodnoi naukovo-praktychnoi konferentsii "Psykholohiia ta pedahohika: neobkhidnist vplyvu nauky na rozvytok praktyky v Ukraini". - Lviv : HO "Lvivska pedahohichna spilnota", 2017. - S. 13-18.

5. Kremen V.H. Dukhovnist i kultura suspilstva vyznachaiutsia rozvytkom osvity Osvita u polikulturnykh suspilstvakh za redaktsiieiu Vasylia Kremenia, Tadeusha Lanovytskoho, Yezhy Nikitorovycha, Svitlany Sysoievoi. - Vyscha pedahohichna shkola SPV. Universytet Bialostotsi. Varshava, 2012. - 392 s. - S. 45-55

6. Krymskyi S. B. Kultura rozkryvaie vnutrishniu bezmezhnist liudyny / Kulturolohichna dumka. 2009. - \# 1. - S. 18-26.

7. Omelchenko E. A. Samovyrazheniie i kultura samovyrazheniia pedagogov i studentov pedagogicheskykh VUZov // Teoriia i praktika obrazovaniia v sovremennom mire : materialy II mezhdunarodnoi nauchnoi konferentsii. - SPb. : Renome, 2012. - S. 11-14.

8. Pidhotovka vykhovatelia do rozvytku osobystosti dytyny v doshkilnomu vitsi : monohrafiia /za zah. red. I. I. Zaharnytskoi. - K.: vyd-vo NPU im. M. P. Drahomanova, 2009. - $310 \mathrm{~s}$.

9. Sysoieva S. O. Osnovy pedahohichnoi tvorchosti : pidruchnyk. - K. : Milenium, 2006. 344 s

Одержано статтю: 05.06.2019

Прийнято до друку: 19.06.2019 